\title{
Unexpected Shutdown
}

National Cancer Institute

\section{Source}

National Cancer Institute. Unexpected Shutdown. NCI Thesaurus. Code C133544.

Problem associated with the device unexpectedly powering down. 